\title{
Late Jurassic-Early Cretaceous oysters from Siberia: A systematic review
}

Igor N. Kosenko

Acta Palaeontologica Polonica 62 (4), 2017: 759-778 doi:https://doi.org/10.4202/app.00387.2017

The present study reviews the taxonomy of Late Jurassic-Early Cretaceous oysters from the Northern and the Subpolar Urals (Western Siberia) and northern East Siberia. Previous studies have documented 10 species from the genus Liostrea (L. delta, L. cucurbita, L. praeanabarensis, $L$. anabarensis, L. plastica, L. gibberosa, L. planoconvexa, L. siberica, L. uralensis, L. lyapinensis ), and 3 species from the genus Gryphaea ( $G$. borealis and 2 species in open nomenclature). Liostrea gibberosa, L. planoconvexa, L. uralensis, and L. cucurbita are transferred in this study to the genus Pernostrea. Furthermore, two new species of Pernostrea are described: P. mesezhnikovi sp. nov. and P.? robusta sp. nov. Liostrea siberica is transferred to the genus Praeexogyra. Liostrea praeanabarensis and L. anabarensis are attributed to the subgenus Boreiodeltoideum (genus Deltoideum ) as well as L. delta sensu Zakharov (1966) which is described here as new species Deltoideum (Boreiodeltoideum) borealis sp. nov. The similar shell morphology of the genera Deltoideum and Pernostrea provides a basis to establish the new tribe Pernostreini trib. nov. in the subfamily Gryphaeinae. Three species are recorded for the first time from Siberia: Nanogyra? cf. thurmanni, "Ostrea" cf. moreana and Gryphaea (Gryphaea) curva.

Key words: Bivalvia, Ostreoidea, Gryphaeidae, Jurassic, Cretaceous, Siberia.

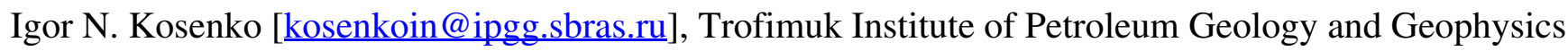
SB RAS, Novosibirsk, 630090, Russia; correspondence address: Novosibirsk State University, Novosibirsk Prospekt Koptyuga 3, Novosibirsk, 630090, Russia.

This is an open-access article distributed under the terms of the Creative Commons Attribution License (for details please see creativecommons.org), which permits unrestricted use, distribution, and reproduction in any medium, provided the original author and source are credited. 
FaF Full text $(1,504.8 \mathrm{kB})$

For ${ }^{2}$ Supplementary file $(787.2 \mathrm{kB})$ 